Energy Sources, 26:441-451, 2004

Copyright (C) Taylor \& Francis Inc.

ISSN: 0090-8312 print/1521-0510 online

DOI: $10.1080 / 00908310490429722$

\title{
Geothermal Fields Suitable for Power Generation
}

\section{GULDEN GOKCEN}

\author{
Mechanical Engineering Department \\ Izmir Institute of Technology \\ Urla, Izmir, Turkey
}

\section{HARUN KEMAL OZTURK}

Department of Mechanical Engineering

Faculty of Engineering

Pamukkale University

Camlik, Denizli, Turkey

\author{
ARIF HEPBASLI \\ Department of Mechanical Engineering \\ Faculty of Engineering \\ Ege University \\ Bornova, Izmir, Turkey
}

\begin{abstract}
Turkey is located on the Mediterranean sector of Alpine-Himalayan Tectonic Belt with many grabens, acidic volcanism, hydrothermal alteration zones, numerous hot springs and fumaroles. The data gathered since 1962 indicate that Turkey has a high geothermal energy potential. By comparison, it is among the first seven countries in abundance of geothermal resources around the world, while the share of its potential used is only about 2\%. This means that considerable studies on geothermal energy could be conducted in order to increase energy supply and to reduce atmospheric pollution in Turkey. The main objective of the present study is threefold, namely: (1) to overview Turkey's geothermal fields suitable for power generation together with their possible utilization opportunities, (2) to present problems encountered and research projects developed in the Denizli-Kizildere geothermal field with an estimated capacity of $200 \mathrm{MW}$ and (3) to assess the current status of geothermal energy use for electric energy production in Turkey. The Denizli-Kizildere geothermal power plant with an installed capacity of $20.4 \mathrm{MW}$, which is, at present, the only operating geothermal power plant of Turkey, was put into operation in 1984, while electricity from geothermal energy has been produced commercially since 1913. This plant produced on average an electrical energy of 84,920 MWh in the period between 1998-2001,
\end{abstract}

Received 29 November 2002; accepted 21 December 2002.

Address correspondence to Arif Hepbasli, Mechanical Engineering Department, Faculty of Engineering, Ege University, 35100 Bornova, Izmir, Turkey. E-mail: hepbasli@ bornova.ege.edu.tr, hepbasli@egenet.com.tr 


\begin{abstract}
representing an average electric power of $10.45 \mathrm{MW}$ in the same period. Parallel to the development of the geothermal energy utilization in the country, it is projected that, by the years 2010 and 2020, the total geothermal power installed capacity will increase to $500 \mathrm{MW} e$ and $1000 \mathrm{MW}$, respectively.
\end{abstract}

Keywords geothermal energy, geothermal fields, electricity generation, power generation, power plant, renewable energy, Kizildere, Turkey

In a number of countries in Europe and worldwide, there is a growing interest in so-called green pricing schemes. The term 'green pricing' is generally understood to describe a program in which customers volunteer to pay more than their regular electricity bill, the additional amount being spent to promote renewable energies. There are other marketoriented schemes for the promotion of renewable energies such as the introduction of quotas, which may be traded. In this context, electricity gained from renewable sources is termed 'green electricity'. The main sources for this green electricity; wind, sun and small hydropower, suffer from cost and availability problems. Geothermal energy, by its nature, has a high availability because the source is not dependent on weather conditions. The awareness of geothermal energy as a possible source of electricity, however, is limited to countries with high enthalpy geothermal sources (Bruhn, 2002).

Geothermal utilization is commonly divided into two categories, namely electric energy production and direct use. Direct or non-electric utilization of geothermal energy consists of various forms for heating and cooling. The major areas of direct use applications are as follows: (a) swimming, bathing and balneology, (b) space heating and cooling including district heating, (c) agriculture applications, (d) aquaculture applications, (e) industrial processes, and (f) heat pumps. In general, the geothermal fluid temperatures required for direct use are lower than those for economic electric power generation (Lund, 1997).

Minimum production temperatures in a geothermal field generally required for different types of uses are characterized by the Lindal diagram, of which modified form is given elsewhere in detail (Lund, 1997; Fridleifsson, 1998). Conventional electric power production is limited to fluid temperatures above $150^{\circ} \mathrm{C}$, but considerably lower temperatures can be used in binary cycle systems, also called organic Rankine cycles. In this case the outlet temperatures of the geothermal fluid are commonly above $85^{\circ} \mathrm{C}$ (Barbier, 2002).

Huttrer $(2000,2001)$ has reviewed the world-wide application of geothermal energy for power generation and reported the following: (a) geothermally-fueled electric power is being generated in 21 nations as of February 2000, (b) the installed capacity has reached $7974 \mathrm{MW}_{\mathrm{e}}$, which is a $16.7 \%$ increase since 1995 , (c) the total energy generated during the last 5 years has been at least 49,261 GWh, and (d) about 1165 wells more than $100 \mathrm{~m}$ deep have been drilled. Huttrer (2001) also concluded that greater increases in the total international installed geothermal generation capacity were inhibited by the economic crisis that occurred in southeast Asia, by the low petroleum prices that prevailed during the 5 year period from 1995 to 2000, and by serious capacity declines at The Geysers field in California, USA.

The share of the top three countries, namely the US, Philippines, and Italy, in total installed capacity of $7974 \mathrm{MW}_{\mathrm{e}}$ in 2000 (with the generation of 49.3 billion $\mathrm{kWh}$ in the same year) was about $27.94 \%, 23.94 \%$ and $9.8 \%$, respectively, followed by Mexico at $9.47 \%$, Indonesia at $7.39 \%$, Japan at $6.85 \%$, New Zealand at $5.48 \%$ and others at $9.13 \%$. By comparison, Turkey accounted for about $0.256 \%$ of the total (Huttrer, 2001; Barbier, 2002).

In this study, Turkey's geothermal fields suitable for power generation are given first. The Denizli-Kizildere geothermal field (DKGF), where Turkey's first and, at present, only 
operating geothermal power plant was installed in 1984, is then investigated. Finally, problems encountered and research projects developed in this field are presented.

\section{Turkey's Geothermal Fields Suitable for Power Generation}

The main geothermal provinces in Turkey may be classified by taking into account the tectonic and volcanic features such as: (a) high and moderate enthalpy fields situated on the graben structure of western Anatolia, (b) the low enthalpy fields on the north Anatolia fault zone related to strike-slip fault and volcanic activity, (c) geothermal systems on the sedimentary basin mainly related to volcanic activity, and (d) systems in mountainous terrain related to volcanism and compression tectonics (Aires-Barros, 1997).

Table 1 illustrates nine geothermal fields of Turkey suitable for generating electricity together with their possible utilization opportunities. High temperature geothermal fields suitable for conventional electricity generation are as follows: Denizli-Kizildere (200$\left.242^{\circ} \mathrm{C}\right)$, Aydin-Germencik $\left(232^{\circ} \mathrm{C}\right)$, Aydin-Salavatli $\left(171^{\circ} \mathrm{C}\right)$, Canakkale-Tuzla $\left(173^{\circ} \mathrm{C}\right)$, Kutahya-Simav $\left(162^{\circ} \mathrm{C}\right)$ and Izmir-Seferihisar $\left(150^{\circ} \mathrm{C}\right)$. The number of the wells in the two geothermal fields, Denizli-Kizildere and Aydin-Germencik, is relatively more than that of the remaining fields. Besides this, geothermal wells drilled are insufficient in the other seven geothermal fields. Therefore, the studies on the determination of the potential of these fields are still in progress (Gunerhan et al., 2001; Akkus et al., 2002).

The only operating geothermal power plant of Turkey is the Denizli-Kizildere geothermal power plant (DKGPP) located near the province of Denizli in Western Anatolia with an installed capacity of $20.4 \mathrm{MW}_{\mathrm{e}}$. The total capacity of the field is estimated to be $200 \mathrm{MW}_{\mathrm{e}}$ (Gunerhan et al., 2001).

The exploration stage is completed in Aydin-Germencik field, which is located on the west of Kizildere. Nine wells have been drilled into a $216-232^{\circ} \mathrm{C}$ reservoir within marbles and quartzites at depths ranging from $285-1500 \mathrm{~m}$. The field capacity is estimated to be $100 \mathrm{MW}_{\mathrm{e}}$. The first stage of the field development is planned to build a $25 \mathrm{MW}_{\mathrm{e}}$ single flash plus binary power plant (GRC, 1998).

The third field with power generation potential is Canakkale-Tuzla Field in northwest Anatolia. The first well was drilled in 1982 . The temperature encountered was $174^{\circ} \mathrm{C}$ in a reservoir at a depth of 333-553 m in volcanic rocks. A second well was drilled to $1020 \mathrm{~m}$. Temperatures up to $174^{\circ} \mathrm{C}$ were recorded, but permeability was low. Another two shallow wells $\left(81\right.$ and $128 \mathrm{~m}$ ) also produced fluid at 146 and $165^{\circ} \mathrm{C}$.

The Aydin-Salavatli field has a reservoir temperature of $171^{\circ} \mathrm{C}$. A $5 \mathrm{MW}_{\mathrm{e}}$ binary or kalina cycle plant with greenhouses or process hot water supply to the industries surroundings was planned in the field but have not realized yet (Tufekcioglu, 1999).

There are also plans to generate $500 \mathrm{MW}_{\mathrm{e}}$ from Germencik, Kizildere, Canakkale and several of the other fields by the year 2010 and $1000 \mathrm{MW}_{\mathrm{e}}$ by 2020 (Huttrer, 2001).

\section{Denizli-Kizildere Geothermal Field}

\section{Brief Historical Development}

Electricity generation from geothermal steam dates back to the beginning of the last century. In fact, commercial generation of electricity from geothermal steam began in Larderello, Tuscany, Italy in 1913 , with an installed capacity of $250 \mathrm{~kW}_{\mathrm{e}}$. However, the first experiments to make use of natural steam to generate electricity date back to 1904, when Prince Piero Ginori Conti coupled a steam-engine to a dynamo to light five bulbs in his boric acid factories at Larderello. Since 1950, other countries have followed the 


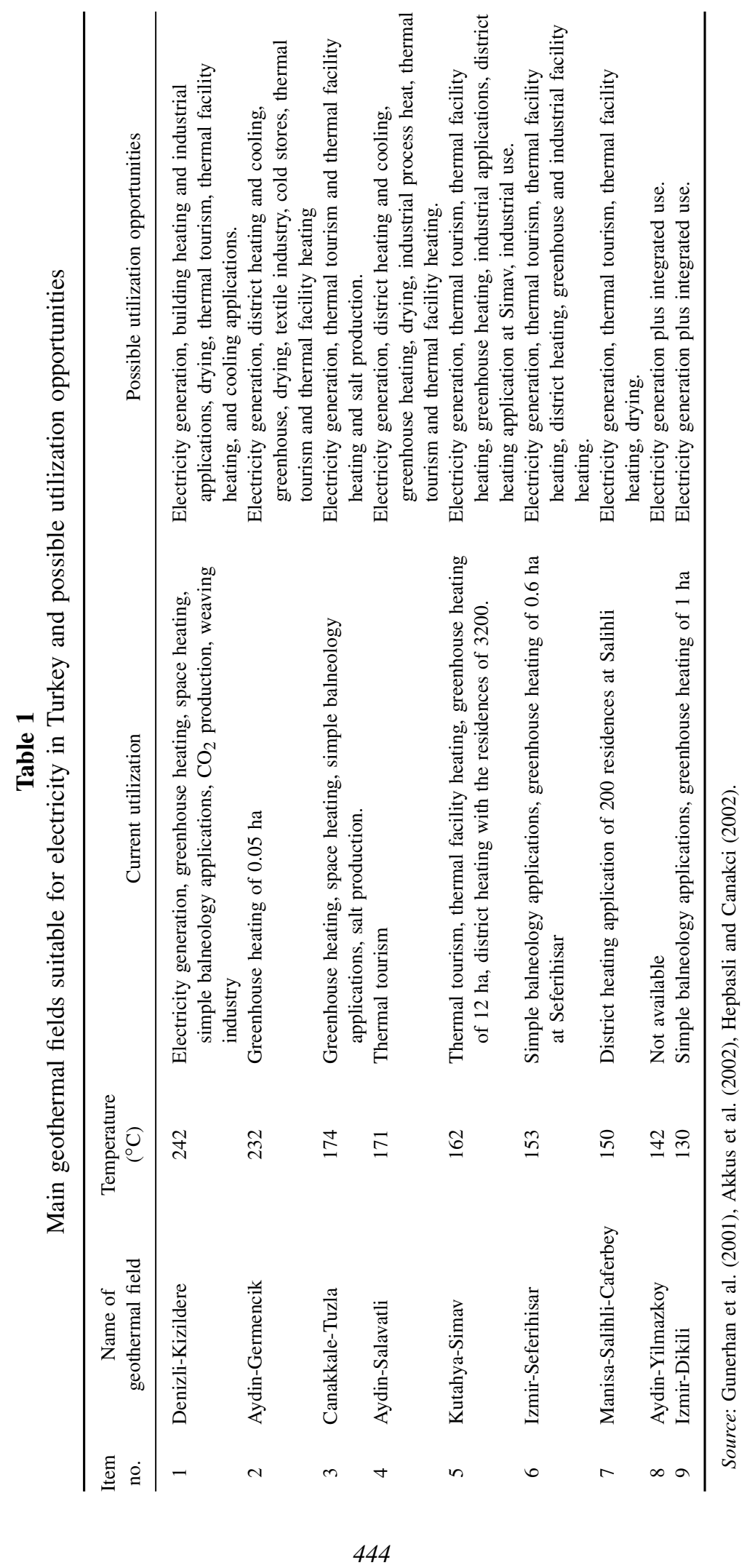


Italian example, and at present electricity is generated from geothermal energy in 21 countries all over the world (Barbier, 2002). The first power plant based on geothermal hot water has been in operation in Wairakei, New Zealand since 1958 (Barbier, 1997; Bruhn, 2002).

The DKGF is located in $30 \mathrm{~km}$ away from the province of Denizli, Western Anatolia, Turkey, while it is the first and only one geothermal field developed in Turkey. Hot springs and fumaroles exist around the field at a wide range of temperature of $30-100^{\circ} \mathrm{C}$.

The evolution in time of the DKGF can be summarized as follows:

- The first geological, geochemical and geophysical studies were performed with support of the United Nations Development Program (UNDP) in 1966.

- The first well was drilled in 1968 with a temperature measured of $198^{\circ} \mathrm{C}$ at a depth of $540 \mathrm{~m}$. A total of 14 wells were drilled between 1968-1973 and the temperatures obtained were in the range $170-212^{\circ} \mathrm{C}$.

- A 0.5 $\mathrm{MW}_{\mathrm{e}}$ pilot plant was installed in 1974 in the field. The electricity generated had met demand of the villages around the field for a long time period. The General Directorate of Mineral Research and Exploitation (MTA) reported that 6 out of 13 wells were suitable for generating electric power.

- The DKGPP was installed in 1984 with an installed capacity of $20.4 \mathrm{MW}_{\mathrm{e}}$. Then, three more production wells were drilled in two years, reaching a total of nine production wells (Sarikurt, 1983). Two stratigraphically separate zones in the field were initially identified as first and second reservoirs during the exploration stage. Shallow reservoir has a temperature of $190-200^{\circ} \mathrm{C}$, a depth of up to $706 \mathrm{~m}$, a steam fraction of $10 \%$ and a moderate permeability. Besides this, the deeper one has a temperature of $200-212^{\circ} \mathrm{C}$, a depth of up to $1241 \mathrm{~m}$, and a steam fraction of $10-12 \%$ and a higher permeability. So, the second reservoir was chosen as production zone.

- In Turkey, the first greenhouse heating system of 0.45 ha by geothermal energy was applied in the DKGF in 1985.

- Because of high non-condensable gas (NCG) content of the field (average 13\% by weight of the steam) and since NCG's consist mainly of $\mathrm{CO}_{2}$ (96-99\%), a liquid $\mathrm{CO}_{2}$ and dry ice production process with an annual capacity of 40,000 tons was built adjacent to the field in 1986. The capacity of the process was increased to 120,000 tons annually in 1999. Besides electricity and dry ice production, the resources of the field have also been used for greenhouse heating and space heating of offices and staff houses of the plant (Simsek, 1985; Simsek and Demirel, 1998).

- In 1997, the so-called R-1 well was drilled for injection purposes. This well intersected a deeper zone $(2261 \mathrm{~m})$ with a temperature of $242^{\circ} \mathrm{C}$ and a steam fraction of $16-18 \%$. The completion tests showed that the well has a high productivity with the values of $103.05 \mathrm{~kg} / \mathrm{s}$ and $6 \mathrm{MW}_{\mathrm{e}}$ (Serpen and Satman, 2000). This well indicated that a third reservoir with a temperature range of $235-245^{\circ} \mathrm{C}$ exists in the DKGF.

- Starting from the commissioning of the plant, the wastewater of the plant had been discharged to the Menderes river with a flow rate of $1000 \mathrm{t} / \mathrm{h}$ and a temperature of $147^{\circ} \mathrm{C}$. In 1986 , it had planned to use this waste heat (about $140 \mathrm{MW}_{\text {th }}$ ) to heat the Denizli city but the pre-feasibility studies have resulted uneconomic in terms of the distance $(33 \mathrm{~km})$ and altitude difference $(200 \mathrm{~m})$ between the field and the city. The project has been actualized in 2001 and the source was considered as a good prospect for Saraykoy town, which is $5 \mathrm{~km}$ away from the field. Geothermal 
fluid at separator exit will be sent to a heat exchanger to transfer its energy to the city circulation water. Then a 9-km long pipeline at a flow rate of $194.5 \mathrm{~kg} / \mathrm{s}$ will carry the clean city water.

- Today, the DKGPP employs 98 people including engineers, technicians and workers, while it operates $8000 \mathrm{~h} / \mathrm{yr}$. The rest is spent for maintenance works such as cleaning the wells and overhaul. Electricity production cost in 2001 was calculated to be 1.75 cents $/ \mathrm{kWh}$.

\section{Main Characteristics}

Main characteristics of the DKGF and DKGPP are given in Table 2 (Sarikurt, 1983; MTA, 1996; Gunerhan, 2000; TEAS, 2002). The DKGF is a liquid dominated system with a steam fraction of $10-12 \%$. Steam field area is $550 \mathrm{~m} \times 650 \mathrm{~m}$, while the calculated reservoir area is $100 \mathrm{~km}^{2}$. The depth of the wells changes from $370 \mathrm{~m}$ to $2261 \mathrm{~m}$. Reservoir temperature is $200-242^{\circ} \mathrm{C}$. Estimated capacity of the field is $200 \mathrm{MW}_{\mathrm{e}}$. The most significant characteristic of the field is the high amount of non-condensable gases $(2.5 \%$ in the reservoir, $5 \%$ by volume of steam, $10-20 \%$ by weight of steam and average $13 \%$ by weight of steam at the turbine inlet) with a $\mathrm{CO}_{2}$ content of $96-99 \%, \mathrm{H}_{2} \mathrm{~S}$ content of 100 $200 \mathrm{ppm}$ and $\mathrm{NH}_{3}$ content of $72 \mathrm{ppm}$ (MTA, 1996). Specific steam consumption of the plant is $10.96 \mathrm{~kg} / \mathrm{kWh}$, while the first law efficiency of the plant is determined to be $11.98 \%$.

Only $10-12 \%$ of brine extracted from the ground turns into steam after the separation process and the remaining $88-90 \%$ had been disposed to the Menderes river by a $1.8-\mathrm{km}$ long channel at an average $147^{\circ} \mathrm{C}$ temperature and a total flow rate of $277.7 \mathrm{~kg} / \mathrm{s}$ from 1984-2002.

Table 2

Some characteristics of the Kizildere geothermal field and plant

\begin{tabular}{lcc}
\hline \multicolumn{1}{c}{ Description } & Unit & Value \\
\hline Reservoir temperature & ${ }^{\circ} \mathrm{C}$ & $200-242$ \\
Wellhead steam fraction & $\%$ & $10-12$ \\
Total dissolved solid (TDS) & $\mathrm{ppm}$ & $2500-3200$ \\
$\mathrm{CO}_{2}$ partial pressure & $\mathrm{MPa}$ & $3.0-5.0$ \\
$\mathrm{NCG}^{2}$ content in steam (by wt) & $\%$ & $10-21$ \\
$\mathrm{CO}_{2}$ content & $\%$ & $96-99$ \\
$\mathrm{H}_{2} \mathrm{~S}$ content & $\mathrm{ppm}$ & $100-200$ \\
Number of production wells & & 9 \\
Optimum wellhead pressure & $\mathrm{MPa}$ & 1.6 \\
& & (because of scaling) \\
Wellhead operation pressure & $\mathrm{MPa}$ & $1.28-1.58$ \\
Wellhead temperature & ${ }^{\circ} \mathrm{C}$ & $180-190$ \\
Total flow rate & $\mathrm{kg} / \mathrm{s}$ & 320.83 \\
NCG flow rate & $\mathrm{kg} / \mathrm{s}$ & 6.1345 \\
Installed capacity & $\mathrm{MW}$ & 20.4 \\
Gross capacity & $\mathrm{MW}$ & 14.0 \\
Net capacity & $\mathrm{MW}$ & 11.2 \\
\hline
\end{tabular}

Source: Sarikurt (1983), MTA (1996), Gunerhan (2000), TEAS (2002). 


\section{Injection System}

The commonly acceptable method of dealing with wastewater is to inject it back into a part of the reservoir.

The first pilot injection test in the DKGF was conducted in 1976 and lasted for 29 weeks. The water produced from well KD-15 was injected into well KD-1A at an average rate of $23.61 \mathrm{~kg} / \mathrm{s}$. Injected water temperature varied from $70^{\circ} \mathrm{C}$ to $80^{\circ} \mathrm{C}$. Well $\mathrm{KD}-1$, which is $68 \mathrm{~m}$ away from $\mathrm{KD}-1 \mathrm{~A}$, was chosen as the observation well. The cooling effect was encountered at the observation well. A heat flow model describing the non-isothermal fluid flow in naturally fractured reservoirs is applied and the temperature behavior in the observation well is predicted.

The second test lasted for 45 days in 1995. The water produced from KD-20 was injected into well KD-7 by gravity. The wellhead injection temperature was $100^{\circ} \mathrm{C}$. Decline in injectivity is related to the possible plugging by scale deposition in the injector. The producer KD-20 also served as an observation well for monitoring the produced water temperature and chloride $\left(\mathrm{Cl}^{-}\right)$concentration. Some change in the chloride content but no change in the temperature of the produced water was observed. Due to the limitations in technical conveniences at that time the actual reasons of plugging difficulty have never been revealed (Satman et al., 2000).

After those trials, an injection well (TH-2) was designed to drill on the other side of the Menderes river, in the Tekkehamam field, which is $3 \mathrm{~km}$ away from the DKGF. The injectivity of the well was poor hence it was abandoned.

Regarding with the injection program of the MTA, another injection well (R-1) was drilled in the DKGF boundary in 1997. The completion tests indicated that the well has high productivity, $103.05 \mathrm{~kg} / \mathrm{s}$ and $6 \mathrm{MW}_{\mathrm{e}}$, and the highest temperature in the field with a bottom hole temperature of $242^{\circ} \mathrm{C}$ at $2261 \mathrm{~m}$. Regarding the data obtained, R-1 well was converted to a production well in 2001 and the production of the plant increased by $6.5 \%$.

Following R-1 well drilling, the MTA conducted some injection trials at abandoned wells in the field in 1998-99, but very fast temperature dropdown was observed in production wells. In 2000, a new injection well (R-2) initiated to drill and completed in 2001 with a depth of $1371 \mathrm{~m}$.

Injection trials in R-2 had been conducted for three months, from May to August 2002. Separated liquid from 2 production wells at $55.55 \mathrm{~kg} / \mathrm{s}$ flow rate and a temperature of $125-135^{\circ} \mathrm{C}$ was injected by gravity. The results of the trials have not been reported yet.

Based upon the injection strategy recommended by Serpen and Satman (2000), the Denizli-Kizildere system would produce from the deeper and hotter third reservoir and inject to the shallow reservoir. Since the third reservoir produces more steam than the second reservoir, which is used as production zone, the amount of water to inject will decrease approximately by half.

\section{Problems Encountered in the Field}

\section{Scaling}

One of the severe problems of the field is scaling problem. In the production wells, precipitation of $\mathrm{CaCO}_{3}$ due to decrease in partial pressure of $\mathrm{CO}_{2}$ occurs; in the injection wells, precipitation of $\mathrm{Si}$ due to temperature dropdown occurs (Giese, 1998). In the field, to solve scaling problem, acid, Dequest 2006 inhibitor and $\mathrm{CO}_{2}$ injection tests were planned and 
only acid and inhibitor injection tests were conducted for 10 months in 1988-1989. The results were successful but because of the high operational cost and contamination potential on groundwater of such applications, mechanical cleaning of the wells once a year was preferred. Production of the wells reaches maximum after cleaning and decreases gradually between two cleaning periods because of the decreasing diameter of the well. Besides cleaning, to reduce the scaling rate, optimum wellhead pressures were determined for each well and the wellhead pressures are kept as high as 1.1-1.94 MPa, but the plant still generates only about $70 \%$ of its installed capacity. The studies indicated that if inhibitors were used, power generation would increase by $25 \%$ (Serpen and Satman, 2000).

\section{Pressure Drop}

The mass balance of the field indicated that production rate exceeds the natural recharge rate of the field. Besides this, during 18 years of operation, injection had not been practiced. As a result of lack of injection and overproduction, in an area of $0.06 \mathrm{~km}^{2}$ in the middle of the field, a pressure drop of 0.05 bar/a $(-5 \mathrm{~m})$ was encountered (Giese, 1998).

\section{Environmental Problems}

Drainage into the Menderes river causes environmental problems due to the heat load and the chemicals in the fluid, especially boron (B).

High boron content of the discharged fluid threatens the agriculture in the region. The wastewater reaches to the river with a boron content of $25 \mathrm{ppm}$. The river is used for irrigation of the Menderes plain, and especially in summer time when the flow rate of the river is low, boron concentration exceeds the upper limit of $1 \mathrm{ppm}$ for irrigation. Injection becomes essential in the field for environmental concerns and reservoir stability.

The DKGF contains a high amount of $\mathrm{CO}_{2}$, which cause a greenhouse effect globally. In Kizildere, $\mathrm{CO}_{2}$ is not rejected to the atmosphere; instead it is extracted as liquid $\mathrm{CO}_{2}$ and dry ice in a plant adjacent to the power plant as an industrial application. $\mathrm{H}_{2} \mathrm{~S}$ content in the field is under the exposure limits.

\section{Research Projects Developed in the Field}

\section{Upstream Reboiler Tests}

The power needed to extract the NCG's from the condenser and discharge them into the atmosphere is supplied by the electricity produced, which seriously impairs the power generation performance (Duthie and Nawaz, 1989). A research project was conducted to remove NCG's from geothermal steam upstream from the turbine to decrease the compressor consumption and increase power plant efficiency. A bench scale experimental unit was set up and tested in the field in 1999. Calculations gave a $35.3 \%$ reduction in parasitic load of the plant, increasing the net capacity by 10.6\% (Gunerhan and Coury, 1999; Gunerhan, 2000).

\section{Boron Removal Tests}

The wastewater of the DKGPP contains boron at approximately $30 \mathrm{ppm}$. The level of boron is high to be used for irrigation in agricultural areas. High concentrations of boron are particularly detrimental for citrus fruits. Therefore, the permitted level of boron in 
irrigation water is $1 \mathrm{ppm}$. To prevent discharge of boron to the Menderes river and to investigate the possibilities of economical boron extraction, some research projects were developed in the field.

Recepoglu and Peker (1991) investigated boron removal from the DKGF wastewater using the boron selective resin Amberlite IRA 743. In the case of Kizildere, with wastewater with a $\mathrm{pH}$ of 8.9 and high $\mathrm{HCO}_{3}$ content, single stage regeneration was found to be feasible and the exhausted resin was found to be regenerated economically. Boron removal after a single stage regeneration with $10 \% \mathrm{H}_{2} \mathrm{SO}_{4}$ was found to be possible.

This work was followed by Badruk et al. (1999a,b) and chelating ion exchange resins Diaion CRB 02 and Purolite S 108 were performed on a quantitative removal of boron from wastewater of the KGF in 1998-1999. Preliminary column tests showed that Diaion CRB 02 is a potential resin for column removal of boron from wastewater of geothermal power plant (Badruk et al., 1999a). Column sorption-elution method was tested as well by Badruk et al. (1999b). The column performances of the same resins for boron removal were observed. N-glucamine type resins Diaion CRB 02 and Purolite S 108 were found to be promising for column removal of boron. It was concluded that a certain emphasis should be given on developing cheaper ion exchange resins with a higher capacity than the resins employed in this work for a cost effective process in which technical objectives are obtained (Badruk et al., 1999b).

\section{Denizli-Kizildere Geothermal Power Plant}

Based on the values for wells drilled, Turkey's geothermal power production potential is estimated to be $764.81 \mathrm{MW}_{\mathrm{e}}$ (Akkus et al., 2002).

The DKGPP is a single flash system with a condensing low-pressure double-flow turbine. This plant operates with a $90 \%$ load factor, while it is described in detail elsewhere (Gunerhan, 2000).

Electricity generation of the DKGPP is illustrated in Figure 1 (TEAS, 2002). As can be seen in this figure, the plant produced on average an electrical energy of 84,920 MWh

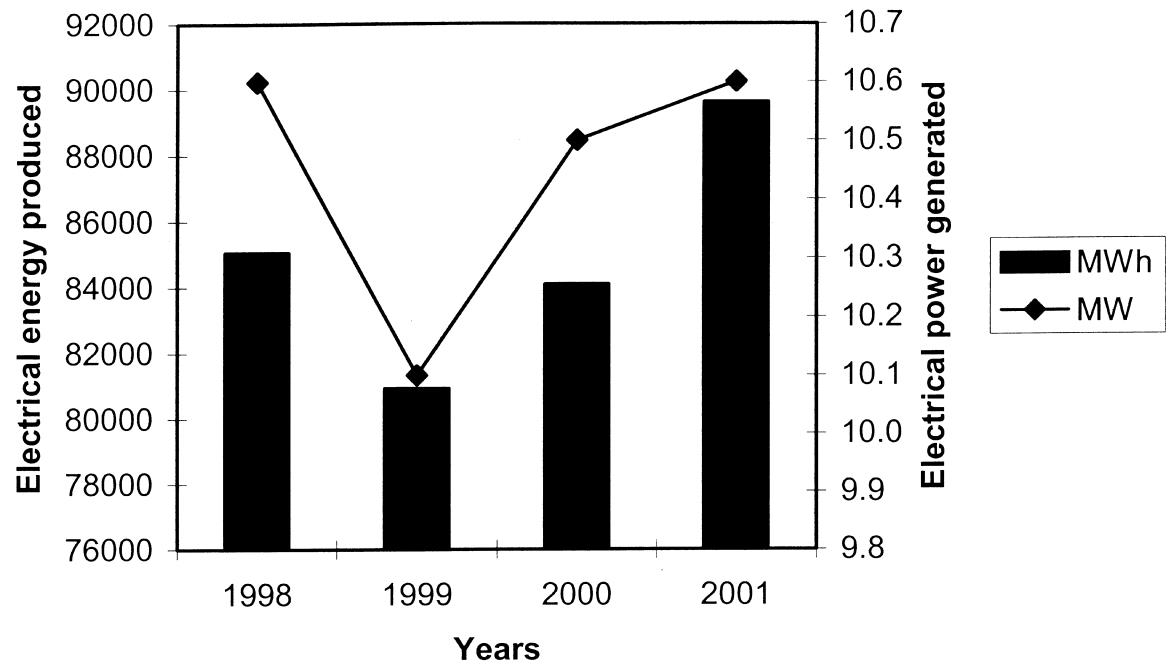

Figure 1. Electricity generation of the Denizli-Kizildere power plant between 1998-2001. Source: TEAS (2002). 
in the period between 1998-2001, representing an average electric power of $10.45 \mathrm{MW}_{\mathrm{e}}$ in the same period.

\section{Conclusions}

Geothermal utilization is commonly divided into two categories, namely electric energy production and direct (or non-electric) uses. This study focused on the former, namely power generation. The main conclusions derived from the present study may be summarized as follows:

- In Turkey, there are nine geothermal fields suitable for generating electricity.

- Based on the values for wells drilled, Turkey's geothermal power production potential is estimated to be $764.81 \mathrm{MW}_{\mathrm{e}}$.

- The only operating geothermal power plant of Turkey is the Denizli-Kizildere geothermal power plant with an installed capacity of $20.4 \mathrm{MW}_{\mathrm{e}}$ and an average electric power produced of $10.45 \mathrm{MW}_{\mathrm{e}}$ between 1998-2001. The total capacity of the field is estimated to be $200 \mathrm{MW}_{\mathrm{e}}$.

- Geothermal wells drilled to date in Turkey, having 170 geothermal fields, are few in numbers. More geothermal wells should be drilled for extending geothermal applications throughout the country.

- There is not any 'geothermal law in Turkey', as yet. There is, however, a 'draft geothermal law'. It is expected that geothermal energy development will significantly increase in the country if this law becomes effective.

\section{References}

Akkus, I., O. Aydogdu, and S. Sarp. 2002. Place of geothermal energy in meeting the energy requirement of our country. In Proceedings of Fourth Clean Energy Symposium, 16-18 October, Istanbul, Turkey. p. 619-628 (in Turkish).

Aires-Barros, L. A. 1997. Geothermal reserves in Europe-Possibilities and justifiableness for development. In Course Textbook on Geothermal District Heating Schemes, eds. K. Dimitrou, O. Mertoglu and K. Popouski, 22-35. International Summer School on Direct Application of Geothermal Energy, in Skopje, Macedonia.

Badruk, M., N. Kabay, N. M. Demircioglu, H. Mordogan and U. Ipekoglu. 1999a. Removal of boron from wastewater of geothermal power plant by selective ion exchange resins (I). Batch sorption-elution studies. Separation Science and Technology 34:2553-2569.

Badruk, M., N. Kabay, N. M. Demircioglu, H. Mordogan and U. Ipekoglu. 1999b. Removal of boron from wastewater of geothermal power plant by selective ion exchange resins (I). Column sorption-elution studies. Separation Science and Technology 34:2981-2995.

Barbier, E. 1997. Nature and technology of geothermal energy: a review. Renewable and Sustainable Energy Reviews 1:1-69.

Barbier, E. 2002. Geothermal energy technology and current status: an overview. Renewable and Sustainable Energy Reviews 6:3-65.

Bruhn, M. 2002. Hybrid geothermal-fossil electricity generation from low enthalpy geothermal resources: geothermal feedwater preheating in conventional power plants. Energy 27:329 346.

Duthie, R. G. and M. Nawaz. 1989. Comparison of direct contact and kettle reboilers to reduce non-condensables in geothermal steam. Transactions of Geothermal Resources Council 13: $575-580$.

Fridleifsson, I. 1998. Geothermal direct use around the world. Geothermal Bulletin 27:235-239.

Giese, L.B. 1998. Seminar on Geothermal Energy. Lecture Notes, Dokuz Eylul University, Izmir, Turkey (unpublished). 
GRC, Geothermal Resources Council. 1998. News briefs. Geothermal Bulletin 27:5.

Gunerhan, G. G. and G. Coury. 1999. Upstream reboiler design and test for removal of noncondensable gases from geothermal steam for Kizildere geothermal power plant. Poster Paper, Geothermal Resources Council Annual Meeting, Reno-Nevada, USA.

Gunerhan, G., G. Kocar, and A. Hepbasli. 2001. Geothermal energy utilization in Turkey. International Journal of Energy Research 25:769-784.

Gunerhan, G. G. 2000. Theoretical and experimental investigations on condensation/boiling modeled heat exchangers (reboilers) designed for removal of noncondensable gases from geothermal steam. Ph.D. Thesis, Graduate School of Natural and Applied Science of Ege University, Bornova, Izmir, Turkey (in Turkish).

Hepbasli, A. and C. Canakci. 2003. Geothermal district heating applications in Turkey: a case study of Izmir-Balcova. Energy Conversion and Management 44:1285-1301.

Huttrer, G. W. 2000. The status of world geothermal power generation 1995-2000. CD-Proceedings of World Geothermal Congress 2000, May 28-June 10. Kyushu-Tohuko, Japan, p. 23-37.

Huttrer, G. W. 2001. The status of world geothermal power generation 1995-2000. Geothermics 30:1-27.

Lund, J. W. 1997. Direct heat utilization of geothermal resources. Renewable Energy 10:403-408.

MTA, General Directorate of Mineral Research and Exploration of Turkey. 1996. Steam Field and Power Plant Data. Personal communication.

Recepoglu, O., and U. Beker. 1991. Preliminary study on boron removal from Kizildere geothermal waste water. Geothermics 20:83-89.

Sarikurt, H. 1983. Kizildere Geothermal Power Plant Report (in Turkish).

Satman, A., U. Serpen, and M. Mihcakan. Assesment of reinjection trials in Kizildere geothermal field. 2000. In CD-Proceedings of World Geothermal Congress 2000, May 28-June 10. Kyushu-Tohuko, Japan, p. 1695-1700.

Serpen, U. and A. Satman. 2000. Reassesment of the Kizildere geothermal reservoir. In $C D$ Proceedings of World Geothermal Congress 2000, May 28-June 10. Kyushu-Tohuko, Japan, p. 2869-2874.

Simsek, S. and Z. Demirel. 1998. Geothermal energy reserves in Turkey. In Proc. of the Int. Workshop. Heating Greenhouses with Geothermal Energy, International Geothermal Days, Azores, Portugal, K. Popovski and A. N. Rodrigues (Eds.), p. 355-366.

Simsek, S. 1985. Present status and future development of the Denizli-Kizildere geothermal field of Turkey. Int. Symposium on Geothermal Energy, Geothermal Resources Council, p. 203-214.

TEAS, 2002. Personal communications.

Tufekcioglu, H. 1999. Ege Energy, personal communication. 